\title{
Grand Challenge: Priorities for Research in Special Educational Needs
}

\author{
Geoff Lindsay* \\ University of Warwick, Coventry, UK
}

Keywords: special educational needs, disabilities, conceptualization, challenges, policy development

In this paper, I propose some priority areas for research in the field of special educational needs (SEN) and disabilities and some additional challenges regarding conceptualization of SEN. As the term "special educational needs and disabilities (SEND)" is now used in England, that term will also be used as appropriate, particularly with reference to the system rather than children and young people.

\section{CONCEPTUALIZATION OF SEN}

Conceptualization of SEN is itself a major challenge, with respect to research and also practices. In the past, children with SEN were viewed primarily with respect to disability. Governments either created separate systems or excluded children with a disability from the education available to typically developing children, either deliberately or by default. For example, it was not until the early 1970s that children with severe or profound learning difficulties, including all those with Down syndrome, were eligible for education in England. Lack of financial resources and expertise was, and continues to be, a major challenge in many countries. Recognition of the rights of all children, however, has led to both a substantial development of positive policies, with substantial funding in some countries, and the necessary development of support through training teachers and others. This has spawned a substantial policy-related research agenda for SEN.

Research has been shaped by changing conceptualizations of SEN. Over time, a substantial body of work has focused on specific categories of children and young people with respect to diagnostic categories, for example, deafness, Down syndrome, cerebral palsy, and mental handicap. Some terms such as mentally handicapped, idiot, imbecile, and educationally subnormal have become unacceptable, considered offensive and demeaning. Other categories, however, have become the foci of substantial research programs, for example, autism spectrum disorders (ASD), dyslexia, attention deficit with hyperactivity disorder (ADHD), and specific language impairment (SLI). Diagnosis of these "conditions" has been a key factor in researchers' selection of samples; furthermore, categories have been fundamental to initiatives to identify and make appropriate provision for children and young people that are identified as being exceptional (Norwich, 2014).

The use of diagnostic categories has benefits for research by specification of samples on key characteristics. But there are also limitations. First, in reality, many children do not just have one type of SEN but, rather, they often have two or even several (Rutter et al., 1970). Research must therefore consider comorbidity and also gender, age, home language if different from that of the school, and ethnicity, as these are associated variables. For example, there is increasing evidence of the overlap in characteristics of children with language impairment and those with ASD (Dockrell et al., 2015). Second, there is concern about the validity and usefulness of many categories, for example, see the recent examination of the usefulness of the diagnostic category SLI (Bishop, 2014; Reilly et al., 2014).

Third, whereas there are strong associations between some types of SEN and certain genetic, chromosomal, perinatal injury, or illness (e.g., rubella) factors, there is now also substantial evidence 
of the impact of external or contextual factors that impair or limit children's development. These include both large scale studies of general populations of children, indicating the very powerful effects of socioeconomic disadvantage (Strand, 2014), parenting (Kiernan and Mensah, 2011), and school effects (Teddlie and Reynolds, 2000; Strand, 2016), which shape children's opportunities for optimal development; and also analyses of total populations of children with a range of SEN, particularly with respect to social disadvantage (Strand and Lindsay, 2009; Department for Education, 2016b).

Conceptualization, and its translation into policy and practice, will continue to pose substantial challenges. There are important national, cultural, legal, and historic factors that impact psychoeducational conceptualizations, resulting in different interpretations and understandings of "special educational needs," and of the requirements of the SEND system in any particular country or state. More international and cross-cultural research is needed to enhance our understanding of the interactions between the within child and contextual factors, which include different cultures.

\section{ACHIEVING POSITIVE OUTCOMES FOR CHILDREN AND YOUNG PEOPLE WITH SEN}

Achieving positive outcomes for children with SEN requires evidence of effectiveness of interventions, for whom and under what circumstances. Studies in some domains, especially literacy, are now numerous and provide an increasingly helpful basis for action (Hattie, 2009). However, the main evidence relates to studies of US practices and, within literacy, is most numerous for reading. More evidence from other countries and other domains (e.g., writing, language, numeracy, and sociobehavioural interventions) is needed: not only more studies but also stronger evidence for interventions as many show small effects (Early Intervention Foundation ${ }^{1}$; Education Endowment Foundation ${ }^{2}$ ).

There are two important issues here: how strong should we expect effects to be in order for an intervention to be considered for implementation; and, what is the practical approach to developing evaluative research? For example, the EIF has developed a grading system for interventions, which presents information on the overall strength of the evidence as well as the strength of effects.

Furthermore, research is needed at each point along the continuum of research evidence: theoretical support for the proposed elements of an intervention; construction of a replicable program, product, practice, or policy; a feasibility study to provide indicative evidence of both effectiveness and practicability; if this is successful, the creation of a manual or guidance to enhance fidelity for implementation; a rigorous efficacy trial under controlled conditions, typically a randomized controlled trial (RCT); at least one replication study by researchers other than the originators to avoid bias or perceived bias (Eisner, 2009); and a scaled up

${ }^{1}$ www.eif.org.uk.

${ }^{2}$ https://educationendowmentfoundation.org.uk/. effectiveness study in natural settings to explore whether the intervention works on large numbers of participants in different settings, for example, children in a number of schools, and/or other educational settings (Lindsay, 2013). Beyond this, further evidence is needed from meta-analyses, and systematic reviews, taking into account the quality of the available studies as well as their findings.

An example of this building of a hierarchy of evidence and the use of evidence to guide policy concerns the use of parenting programs to improve parenting skills and reduce child behavioral difficulties. Substantial numbers of studies provide evidence of the efficacy of specific programs [e.g., Nowak and Heinrichs (2008), Dretzke et al. (2009), United Nations Office on Drugs and Crime (2010), Sanders et al. (2011), and Furlong et al. (2012)]. The UK government, on the basis of a review of parenting programs (Moran et al., 2004), funded an effectiveness trial of three parenting programs in 18 local authorities (LAs) in England. On the basis of positive evidence for the programs' effectiveness and relative effectiveness across the programs (Lindsay et al., 2011b) a national roll out to implement the program in all English LSs was funded; this demonstrated a maintenance of effectiveness after the scale-up to national level (Lindsay et al., 2011c; Lindsay and Strand, 2013).

Evidence-based policy and practice is made easier when web-based databases that provide substantial information on the effectiveness of interventions are available to policy makers, commissioners, and practitioners - and indeed parents and young people with SEN. Examples include the What Works Clearing House in the US ${ }^{3}$, and both the Early Intervention Foundation (see text footnote 1) and Education Endowment Foundation (see text footnote 2) in the UK. With respect specifically to children with speech and language difficulties, the What Works for Speech, Language and Communication Needs (SLCN) is hosted by the Communication Trust ${ }^{4}$; see also Law et al. $(2012,2015)$. This was developed through the Better Communication Research Programme (Dockrell et al., 2015) as part of the UK government's Better Communication Action Plan (Department for Children, Schools and Families, 2008), in response to the Bercow review of provision for children and young people with SLCN (Bercow, 2008; Lindsay et al., 2010).

Other areas of research to improve children's outcomes include methods to increase the expectations held for students with SLCN by parents and educators, and the aspirations held by the young people themselves (Kintrea et al., 2011; Cummings et al., 2012; Gorard et al., 2012), and methods for improving teachers' attitudes, confidence, knowledge, and skills (Department for Education, 2011; Lindsay et al., 2011a).

\section{THE ORGANIZATION OF SEN DELIVERY}

Inclusive education is now a leading policy for service delivery in many countries, despite limited evidence for its effectiveness

${ }^{3}$ The Communication Trust - What Works? Available at: http://www.thecommunicationtrust.org.uk/whatworks.

${ }^{4}$ What Works Clearinghouse. Available at: http://ies.ed.gov/ncee/wwc/. 
(Lindsay, 2007). We need well-designed studies of what works in inclusive settings, including the delivery of SEND support services and their collaboration with front line professionals in order to develop effective pedagogies and practice (Lewis and Norwich, 2005). Descriptive research studies provide interesting indicative evidence but carefully designed studies of interventions in inclusive settings to test effectiveness are required. For example, response to interventions (RTIs) has gained much momentum as an approach, with its emphasis on assessment, monitoring, and review, rather than "diagnosis." Since RTI's evidence base has been questioned (Reynolds and Shaywitz, 2009), more research on its usefulness in different systems is warranted.

The use of paraprofessionals [teaching assistants (TAs)] in classrooms and early learning centers has the potential for lower cost interventions. However, the mixed research base (Blatchford et al., 2009) indicates the need for well-controlled studies of careful interventions based on revised practice by TAs, guided by the research to date, in order to improve practice (Sharples et al., 2015).

\section{THE EXPERIENCES OF CHILDREN AND YOUNG PEOPLE WITH SEN, THEIR PARENTS AND PRACTITIONERS}

Investigations of the experience of those involved in the SEND system are important to access the voice of children and parents about the implementation of the system, its successes, and limitations. It is important to access children's perspectives of their different educational experiences, including the learning process and academic progress; their social and emotional development, including peer relationships; and their aims for their future (Lewis et al., 2007; Roulstone and Lindsay, 2012). Involving children and young people in research requires the development of research methods appropriate to their competencies, another area for research development (Lewis and Lindsay, 2000; Lewis et al., 2007; Roulstone and Lindsay, 2012).

Parents have important perspectives on their children's educational experience and development and on the SEND system, its positive aspects and areas for improvement (Lindsay and Dockrell, 2004; Lamb, 2009; Parsons et al., 2009; Tissot, 2011; Lindsay et al., 2016). The views of professionals are also important, including their reflections on their own abilities to address the needs of the students they teach (Dockrell and Lindsay, 2001), their pedagogic engagement with parents (Watson and Swanwick, 2008), and their contribution to the development of the SEND system. For example, the UK Government's Children and Families Act 2014 requires that the Local Offer of services and provision for children and young people with SEN in each LA in England be co-constructed by professionals with parents and young people (Spivack et al., 2014).

\section{COST-EFFECTIVENESS}

There is a clear socio-political requirement for studying costeffectiveness and cost-benefit analysis of SEND provision
(National Audit Office, 2011, 2015). In England, for example, total spend on SEND is substantial ( $£ 5.8$ billion during 2011-2012) and per capita education spend for children with SEN is substantially higher than that for typically developing children (Department for Education, 2016a). There are also considerable variations in costs between schools and LAs and between children with different categories of SEN as their primary area of need - are these justified?

The case for cost-effectiveness studies starts with the cost savings that could be made over the lifetime if the poor progress and achievement of children and young people with SEN could be prevented or at least reduced, for example, by earlier intervention (Heckman and Masterov, 2007; Field, 2010; Allen, 2011). Studies are also needed of the cost and cost-effectiveness of different systems of provision, for example, attendance at a mainstream state (public) school or a special school (Crowther et al., 1998; Clifford and Theobald, 2012) or of the models for state funding of schools for the support of students with SEN (Parish and Bryant, 2015) and the use of TAs (Keslair et al., 2011). Indeed, there are recent and current attempts to address such issues in England, through the government funded study of pathfinder LAs trialing the new systems necessary as a result of the Children and Families Act (Craston et al., 2014).

Research into the cost-effectiveness of different forms of interventions is also important. Studies have indicated the costeffectiveness of evidence-based parenting programs, for example, in reducing health inequalities (O'Neill et al., 2013) and of delivering parenting programs in "real life" community settings on a large scale (Lindsay et al., 2011b,c, 2014; Lindsay and Strand, 2013). Examining "dosage", that is the effectiveness and costeffectiveness of different patterns of delivery of an intervention, in terms of their intensity, a function of the intervention itself ("dose"), the "dose" frequency, and total intervention duration is also necessary (Zeng et al., 2012).

\section{CONCLUSION}

I have focused on five groups of challenges for research in SEN: the conceptualization of the field of SEND; achieving positive outcomes for children and young people with SEN; the organization and delivery of SEND services; capturing the experiences of children and young people with SEN, their parents and practitioners; and cost-effectiveness or value for money. These themes are not exhaustive. They also overlap with other themes that a challenging research agenda must address, including capturing international practice and policy development; ethical factors in SEN research; the needs and development of the relevant professions working with children and young people with SEN, including teachers, TAs (paraprofessionals), and educational (school) psychologists; and the development of appropriate research methods. There is also the potential for important findings to come from the field of neuroscience (Goswami, 2014), although caution is necessary as there is a history of exaggerated claims for effects which are not substantiated by research evidence (Frederickson and Cline, 2015).

This is an exciting, non-exclusive research agenda for SEND and for the new journal Frontiers in Education: Special Educational 
Needs. I am delighted to have been appointed Chief Specialist Editor for the journal, and I look forward to receiving high quality papers on these and other relevant topics from researchers across the world.

\section{REFERENCES}

Allen, G. (2011). Early Intervention: Smart Investment, Massive Savings. The Second Independent Report to Her Majesty's Government. Available at: https://www. gov.uk/government/uploads/system/uploads/attachment_data/file/61012/ earlyintervention-smartinvestment.pdf

Bercow, J. (2008). The Bercow Report: A Review of Services for Children and Young People (0-19) with Speech, Language and Communication Needs. London: Department for Children, Schools and Families.

Bishop, D. V. M. (2014). Ten questions about terminology for children with unexplained language problems. Int. J. Lang. Commun. Disord. 49, 381-415. doi:10.1111/1460-6984.12101

Blatchford, P., Bassett, P., Brown, P., and Webster, R. (2009). The effect of support staff on pupil engagement and individual attention. Br. Educ. Res. J. 35, 661-686. doi:10.1080/01411920902878917

Clifford, J., and Theobald, C. (2012). National Association of Independent and Non-Maintained Special Schools: Summary of Findings: Extension of the 2011 Cost Comparison Methodology to a Wider Sample. Available at: http:// www.nasschools.org.uk/wp-content/uploads/sites/9/2014/08/NASS-CostComparison-Report-October-2012.pdf

Craston, M., Carr, C., Spivack, R., and Thom, G. (2014). Evaluation of the Special Educational Needs and Disability Pathfinder Programme: Understanding the Comparative Costs of Delivering the EHC Planning and SEN Statementing Processes for Newcomers to the SEN System. Available at: https://www.gov. uk/government/uploads/system/uploads/attachment_data/file/342285/ RR356B_-_Comparative_Costs_Evaluation.pdf

Crowther, D., Dyson, A., and Millward, A. (1998). Costs and Outcomes for Pupils with Moderate Learning Difficulties in Special and Mainstream Schools. RR 89. London: Department for Education.

Cummings, C., Laing, K., Law, J., McLaughlin, J., Papps, I., Todd, L., et al. (2012). Can Changing Aspirations and Attitudes Impact on Educational Attainment? A Review of Interventions. York: Joseph Rowntree Foundation.

Department for Children, Schools and Families. (2008). Better Communication Action Plan. Nottingham: Department for Children, Schools and Families.

Department for Education. (2011). Support and Aspiration: A New Approach to Special Educational Needs and Disability. London: TSO.

Department for Education. (2016a). School Revenue Funding: Current Funding Arrangements. Available at: https://consult.education.gov.uk/funding-policy-unit/schools-national-funding-formula/supporting_documents/ Current_funding_system.pdf

Department for Education.(2016b).DfE Statistical First Release: SpecialEducational Needs in England: 2015. Available at: https://www.gov.uk/government/uploads/ system/uploads/attachment_data/file/447917/SFR25-2015_Text.pdf

Dockrell, J., and Lindsay, G. (2001). Children with specific speech and language difficulties: the teachers' perspectives. Oxford Rev. Educ. 27, 369-394. doi: $10.1080 / 03054980125168$

Dockrell, J., Lindsay, G., Roulstone, S., and Law, J. (2015). Supporting children with speech language and communication needs: an overview of the results of the Better Communication Research Programme. Int. J. Lang. Commun. Disord. 49, 543-557. doi:10.1111/1460-6984.12089

Dretzke, J., Davenport, C., Frew, E., Barlow, J., Stewart-Brown, S., Bayliss, S., et al. (2009). The clinical effectiveness of different parenting programmes for children with conduct problems: a systematic review of randomized control trials. Child Adolesc. Psychiatry Ment. Health 3, 7. doi:10.1186/17532000-3-7

Eisner, M. (2009). No effects in independent prevention trials: can we reject the cynical view? J. Exp. Criminol. 5, 163-183. doi:10.1007/s11292-0099071-y

Field, F. (2010). The Foundation Years: Preventing Poor Children Becoming Poor Adults. The Report of the Independent Review on Poverty and Life Chances.

\section{AUTHOR CONTRIBUTIONS}

The author confirms being the sole contributor of this work and approved it for publication.

London: HM Government. Available at: http://webarchive.nationalarchives.gov. uk/20110120090128/http://povertyreview.independent.gov.uk/media/20254/ poverty-report.pdf

Frederickson, N., and Cline, T. (2015). Special Educational Needs, Inclusion and Diversity, 3rd Edn. Maidenhead: Open University Press.

Furlong, M., McGilloway, S., Bywater, T., Hutchings, J., Smith, S. M., and Donnelly, M. (2012). Behavioural and cognitive-behavioural group-based parenting programmes for early-onset conduct problems in children aged 3-12 years. Cochrane Database Syst. Rev. 2, CD008225. doi:10.1002/ 14651858

Gorard, S., See, B. H., and Davies, P. (2012). The Impact of Attitudes and Aspirations on Educational Attainment and Participation. York: Joseph Rowntree Foundation.

Goswami, U. (2014). "Educational neuroscience: bridging the gulf between basic research and implications for practice," in The Sage Handbook of Special Education, Rev. Edn, Vol. 1, ed. L.Florian (London: SAGE), $315-332$.

Hattie, J. (2009). Visible Learning: A Synthesis of Over 800 Meta-Analyses Relating to Achievement. Abingdon: Routledge.

Heckman, J. J., and Masterov, D. V. (2007). The Productivity Argument for Investing in Young Children. Available at: http://jenni.uchicago.edu/human-inequality/ papers/Heckman_final_all_wp_2007-03-22c_jsb.pdf

Keslair, F., Maurin, E., and McNally, S. (2011). Every Child Matters? An Evaluation of "Special Educational Needs" Programmes in England, CEP, London School of Economics and IZA, Discussion Paper No. 6069. Available at: http://ftp.iza.org/ dp6069.pdf

Kiernan, K. E., and Mensah, F. K. (2011). Parenting, family resources and children's early educational attainment: the mediating role of parenting. Br. Educ. Res. J. 37, 317-336. doi:10.1080/01411921003596911

Kintrea, K., St Clair, R., and Houston, M. (2011). The Influence of Parents, Places and Poverty on Educational Attitudes and Aspirations. York: Joseph Rowntree Foundation.

Lamb, B. (2009). Lamb Inquiry: Special Educational Needs and Parental Confidence. Nottingham: DCSF Publications. Available at: https://www.education.gov.uk/ publications/eOrderingDownload/01143-2009DOM-EN.pdf

Law, J., Lee, W., Roulstone, S., Wren, Y., Zeng, B., and Lindsay, G. (2012). "What Works": Interventions for Children and Young People with Speech, Language and Communication Needs: Technical Annex. London: DfE, 168. Available at: https://www.education.gov.uk/publications/standard/publicationDetail/ Page1/DFE-RR247-BCRP10

Law, J., Roulstone, S., and Lindsay, G. (2015). Integrating external evidence of intervention effectiveness with both practice and parent perspective: development of 'What Works' for speech, language and communication needs (SLCN). Dev. Med. Child Neurol. 57, 223-228. doi:10.1111/dmcn.12630

Lewis, A., and Lindsay, G. (eds) (2000). Researching Children's Perspectives. Buckingham: Open University Press.

Lewis, A., and Norwich, B. (2005). Special Teaching for Special Children? A Pedagogy for Inclusion? Maidenhead: Open University Press.

Lewis, A., Parsons, S., and Robertson, C. (2007). My School, My Family, My Life: Telling It Like It Is. Birmingham: Disability Rights Commission/Birmingham: University of Birmingham.

Lindsay, G. (2007). Educational psychology and the effectiveness of inclusive education/mainstreaming. Br. J. Educ. Psychol. 77, 1-24. doi:10.1348/0007099 06X156881

Lindsay, G. (2013). The benefits of combined (mixed) methods research: the large scale introduction of parenting programmes. Soc. Work Soc. Sci. Rev. 16, 76-87. doi:10.1921/1003160202

Lindsay, G., Cullen, M. A., Cullen, S., Dockrell, J., Strand, S. D., Arweck, E., et al. (2011a). Evaluation of Impact of DfE Investment in Initiatives Designed to Improve Teacher Workforce Skills in Relation to SEN and Disabilities. DFE-RR115. 
London: DfE. Available at: https://www.education.gov.uk/publications/RSG/ AllRsgPublications/Page3/DFE-RR115

Lindsay, G., Strand, S., and Davis, H. (2011b). A comparison of the effectiveness of three parenting programmes in improving parenting skills, parent mental well being and children's behaviour when implemented on a large scale in community settings in 18 English local authorities: the Parenting Early Intervention Pathfinder (PEIP). BMC Public Health 2011:962. doi:10.1186/1471-2458$11-962$

Lindsay, G., Strand, S., Cullen, M. A., Cullen, S., Band, S., Davis, H., et al. (2011c). Parenting Early Intervention Programme evaluation: DFE-RR121A. London: DfE. Available at: https://www.education.gov.uk/publications/eOrderingDownload/DFE-RR121A.pdf

Lindsay, G., Cullen, M. A., Cullen, S., Totsika, V., Bakopoulou, I., Goodlad, S., et al. (2014). CANparent Trial Evaluation: Final Report. Research Report DFE-RR357. Available at: https://www.gov.uk/government/publications/ canparent-trial-evaluation-final-report

Lindsay, G., and Dockrell, J. (2004). Whose job is it? Parents' concerns about the needs of their children with language problems. J. Spec. Educ. 37, 225-236. doi:10.1177/00224669040370040201

Lindsay, G., Dockrell, J. E., Desforges, M., Law, J., and Peacey, N. (2010). Meeting the needs of children with speech, language and communication difficulties. Int. J. Lang. Commun. Disord. 45, 448-460. doi:10.3109/13682820903165693

Lindsay, G., Ricketts, J., Peacey, L., Dockrell, J., and Charman, T. (2016). Meeting the educational and social needs of children with language impairment or autism spectrum disorder: the parents' perspectives. Int. J. Lang. Commun. Disord. 51, 495-507. doi:10.1111/1460-6984.12226

Lindsay, G., and Strand, S. (2013). Evaluation of a national roll-out of parenting programmes across England: the parenting early intervention programme (PEIP). BMC Public Health 13:972. doi:10.1186/10.1186/1471-2458-13-972

Moran, P., Ghate, D., and van der Werwe, A. (2004). What Works in Parenting Support? A Review of the International Literature. Research Report 574. London: Department for Education and Skills.

National Audit Office. (2011). Oversight of Special Education for Young People Aged 16-25. Available at: http://www.nao.org.uk/wp-content/uploads/2012/ 01/841303f2-e9b3-4916-b217-583edffe633a1.pdf

National Audit Office. (2015). Funding for Disadvantaged Pupils. Available at: http://www.nao.org.uk/wp-content/uploads/2015/06/Funding-fordisadvantaged-pupils.pdf

Norwich, B. (2014). "Categories of special educational needs," in The Sage Handbook of Special Education, Rev Edn, Vol. 1, ed. L.Florian (London: SAGE), 55-73.

Nowak, C., and Heinrichs, N. (2008). A comprehensive meta-analysis of Triple P-Positive Parenting Program using hierarchical linear modelling: effectiveness and moderating variable. Clin. Child Fam. Psychol. Rev. 11, 114-144. doi:10.1007/s10567-008-0033-0

O’Neill, D., McGilloway, S., Donnelly, M., Bywater, T., and Kelly, P. (2013). A cost-effectiveness analysis of the Incredible Years parenting programme in reducing childhood health inequalities. Eur. J. Health Econ. 14, 85-94. doi:10.1007/s10198-011-0342-y

Parish, N., and Bryant, B. (2015). Research on Funding for Young People with Special Educational Needs: Research Report. Available at: https://www.gov. uk/government/uploads/system/uploads/attachment_data/file/445519/ DFE-RR470_-_Funding_for_young_people_with_special_educational_ needs.pdf

Parsons, S., Lewis, A., and Ellins, J. (2009). The views and experiences of parents of children with autistic spectrum disorder about educational provision: comparisons with parents of children with other disabilities from an online survey. Eur. J.Spec. Needs Educ. 24, 37-58. doi:10.1080/ 08856250802596790
Reilly, S., Tomblin, B., Law, J., McKean, C., Mensah, F. K., Morgan, A., et al. (2014). Specific language impairment: a convenient label for whom? Int. J. Lang. Commun. Disord. 49, 416-451. doi:10.1111/1460-6984.12102

Reynolds, C. R., and Shaywitz, S. E. (2009). Response to intervention: ready or not? Or, from wait-to-fail to watch-them-fail. School Psychol. Q. 24, 130. doi:10.1037/ a0016158

Roulstone, S., and Lindsay, G. (2012). The Perspectives of Children and Young People Who Have Speech, Language and Communication Needs, and Their Parents. London: DfE. Available at: https://www.education.gov.uk/publications/ standard/publicationDetail/Page1/DFE-RR247-BCRP7

Rutter, M., Tizard, J., and Whitmore, K. (1970). Education, Health and Behaviour. London: Longman.

Sanders, M. R., Kirby, J. N., Tellegen, C. L., and Day, J. J. (2011). The Triple P Positive Parenting Program: a systematic review and meta-analysis of a multilevel system of parenting support. Clin. Psychol. Rev. 34, 337-357. doi:10.1016/j. cpr.2014.04.003

Sharples, J., Webster, R., and Blatchford, P. (2015). Making Best Use of Teaching Assistants: Guidance Report. London: Education Endowment Foundation. Available at: https://v1.educationendowmentfoundation.org.uk/uploads/pdf/ TA_Guidance_Report_Interactive.pdf

Spivack, R., Hallam, R., and Thom, G. (2014). Evaluation of the Special Educational Needs and Disability Pathfinder Programme. Thematic Report: The Local Offer. Available at: https://www.gov.uk/government/uploads/system/uploads/ attachment_data/file/380110/RR429A_-_Evaluation_of_the_SEND_pathfinder_programme_local_offer.pdf

Strand, S. (2010). Do some schools narrow the gap? Differential school effectiveness revisited. Rev. Educ. doi:10.1080/09243451003732651

Strand, S. (2014). Ethnicity, gender, social class and achievement gaps at age 16: intersectionality and 'getting it' for the white working class. Res. Papers Educ. 29, 131-171. doi:10.1080/02671522.2013.767370

Strand, S., and Lindsay, G. (2009). Evidence of ethnic disproportionality in special education in an English population. J. Spec. Educ. 43, 174-190. doi:10.1177/0022466908320461

Teddlie, C., and Reynolds, D. (2000). The International Handbook of School Effectiveness Research. London: Falmer Press.

Tissot, C. (2011). Working together? Parent and local authority views on the process of obtaining appropriate educational provision for children with autism spectrum disorders. Educ. Res. 53, 1-15. doi:10.1080/00131881.2011.552228

United Nations Office on Drugs and Crime. (2010). Compilation of Evidence-Based Family Skills Training Programmes. New York: United Nations.

Watson, L., and Swanwick, R. (2008). Parents' and teachers' views on deaf children's literacy at home: do they agree? Deafness Educ. Int. 10, 22-39. doi:10.1002/ dei.235

Zeng, B., Law, J., and Lindsay, G. (2012). Characterising optimal intervention intensity: the relationship between dosage and effect size in interventions for children with developmental speech and language difficulties. Int. J. Speech Lang. Pathol. 14, 471-477. doi:10.3109/17549507.2012.720281

Conflict of Interest Statement: The author declares that the research was conducted in the absence of any commercial or financial relationships that could be construed as a potential conflict of interest.

Copyright $\odot 2016$ Lindsay. This is an open-access article distributed under the terms of the Creative Commons Attribution License (CC BY). The use, distribution or reproduction in other forums is permitted, provided the original author(s) or licensor are credited and that the original publication in this journal is cited, in accordance with accepted academic practice. No use, distribution or reproduction is permitted which does not comply with these terms. 